\title{
abiblíograpbícal æRecord.
}

ART. I.-The Psychology of Shakspeare. By John Charles Bucknilu, M.D. Lond., Licentiate of the Royal College of Physicians; Fellow of University College, London ; Medical Superintendent of the Devon County Lunatic Asylum; editor of "The Journal of Mental Science,' and joint-author of 'The Manual of Psychological Medicine.'-London, 1859. pp. 264.

That a physician devoted to the treatment of "the mind diseased," but especially one who has proved himself to be so intimately acquainted with the physiological and pathological psychology as Dr. Bucknill has, should find in Shakspeare much subject for study and contemplation, is not to be wondered at. What but the reality of his characters, their vitality and truthfulness, the absence of mere histrionic conventionalities, has made Shakspeare the poet of the world? He, indeed, as our author well says, is the great mind which, containing all possibilities within itself, and combining the knowledge of others with the knowledge of self, was able to conceive and to delineate every variety of character possible in nature. As Shakspeare's representations of the normal manifestations of character surpass the representations of all other authors of fiction, so do we nowhere find the transition from the healthy to the morbid condition of the mind, the various phases of insanity and the difference between real and feigned madness, delineated as we see it in the plays of our immortal poet. Opportunities; our author tells us, were plentiful for observing the phenomena of mental derangement in the good old days. The insane members of society were not in those times confined in lunatic asylums or placed under the protection of Commissioners in Lunacy. "If their symptoms were prominent and dangerous, they were indeed thrust out of sight very harshly and effectually, but if their liberty was in any degree tolerable, it was tolerated, and they were permitted to live in the family circle or to wander the country." Hence, Shakspeare had not to seek far for subjects of study, and his great mind sufficed "to convert these opportunities into psychological science."

Dr. Bucknill shows how Shakspeare's knowledge of the mental physiology of human life was brought to bear upon all the obscurities and intricacies of its pathology; how he, above all men, had the faculty of unravelling the motives of human action. In the work before us the 
author analyses, in a masterly manner, the mental phenomena of several of the more prominent characters of the world's poet, and brings ample proofs how, even in her morbid manifestations, Shakspeare mirrors Nature as none eise has done. It has been a source of great pleasure to us to read Dr. Bucknill's book, and we hope soon again to peruse it, when, under his guidance, we have gone over carefully the dramas upon which he descants. We congratulate the literary world upon the appearance of a work which must be a great boon to all ordinary commentators, to whom the human mind is only known in a few of its features. But Dr. Bucknill opens to us new views; he gives us additional grounds for paying our homage, we had almost said devotion, to the creative genius of Shakspeare; and his inquiries are not vague and vain speculations, but put before us in language worthy of its subject, arguments based upon a kind of knowledge which no previous commentator of Shakspeare has possessed. The series commences with an inquiry into the characters of Macbeth and Lady Macbeth; its general scope may be gathered from the following introductory remark-

"Although Macbeth is less perraded with the idea of mental disease than its great rival tragedies of Hamlet and Lear, and contains but one short scene in which a phase of insanity is actually represented, it is not only replete with passages of deep psychological interest, but in the mental development of the bloody-handed hero and of his terrible mate, it affords a study scarcely less instructive than the wild and passionate madness of Lear, or the metaphysical motive-weighing melancholy of the Prince of Denmark."

Dr. Bucknill commences his analysis by demonstrating that the moral basis of Macbeth's character is by no means one of innate badness, but that his natural tendencies are to bravery and kindness. His ambition is the idol which, under the fostering influence of the baneful prophecy, and of the still more ambitious wife, leads him to the commission of his first foul deed, and having once overstepped the bounds of morality and humanity, his career in wickedness can no longer be arrested. Let us hear our author's words-

"Macbeth is no villain in grain, like Richard III. or Iago, revelling in the devil's work because he likes it; but a once noble nature, struggling, but. yielding, in a net of temptation, whose meshes are wound round him by the visible hand of the Spirit of Evil. Slave as he is to that soldier's passion, the love of fame and power, he is not without amiable qualities. He was once loved even by his arch-enemy Macduff, to whom Malcolm says-

$$
\begin{aligned}
& \text { " This tyrant, whose sole name blisters our tongues, } \\
& \text { Was once thought honest; you have loved him well." }
\end{aligned}
$$

Dr. Bucknill urges further arguments on the same side, but he has no wish in that way to palliate the guilt of Macbeth-

"In a moral point of view this is impossible. If his solicitings to crime are supernatural, combined with fate and metaphysic aid, he is not blinded by them. With conscience fully awake, with eyes open to the foul nature of his double treachery, although resisting, he yields to temptation. He even feels that he is not called upon to act to fulfil the decrees of destiny-

" If chance will have me king, why chance may crown me, Without my stir.' 
"Had he with more determination resisted the temptations of the woman, he might have falsified the prophecies of the fiend, and put aside from his lips the poisoned chalice of remorse, maintained from rancours the vessel of his peace, and above all, have rescued the eternal jewel of his soul."

It is impossible for us to accompany Dr. Bucknill in his wanderings through those realms which Shakspeare has opened to us, but which, like so many other good and glorious things that lie within our reach, we but rarely appreciate and love as they merit. We may vaguely admire his works, as a man of taste feels his heart warmed by the picturesque scenery of the mountains and valleys of Wales or Scotland; but deeper knowledge and a larger mind than that which indulges only in dilettantism, is necessary to enjoy to the full, the grandeur or loveliness of nature; and alike, those wonderful representations of man in all the phases in which he treads the earth, which Shakspeare places before us.

Willingly would we dwell longer upon this interesting and fruitful theme. We feel that were we able to devote more space to it, we could but feebly follow in the footsteps of Dr. Bucknill, whose knowledge and appreciation of Shakspeare's characters makes him a fit expositor of his favourite poet. No one, we conceive, has so admirably and consistently traced the unity of character that pervades Hamletthe most wonderful, as well as the most intricate, of Shakspeare's dramas. Sincerely do we hope that Dr. Bucknill will continue his sketches, and more particularly that he will at once carry out the plan which he bas already formed, of giving to the world his views regarding Shakspeare's knowledge of medicine.

Art. II.-Five Essays. By John Kearsley Mrtcheld, M.D., late Professor of Practice of Medicine in Jefferson Medical College of Philadelphia, Member of the Academy of Natural Sciences of Philadelphia, Fellow of the Philadelphia College of Physicians, \&c. Edited by S. Weir Mitchell, M.D., Lecturer on Physiology in the Philadelphia Association for Medical Instruction. - Phitadelphia, 1859 . pp. 371.

The five essays which constitute this volume have all-four in toto, one in extract-been already before the public of the United States; some of our readers may therefore have become acquainted with them. They now, however, for the first time make their appearance in a collected form, and we may thank the editor for having performed what the 'Charlestown Medical Journal' terms an act of filial reverence in publishing them together. The book itself gives us no clue to the relationship that links the two names together which are found on the title-page.

The first of these essays discusses the cryptogamous origin of malarious and epidemic fevers, in which the author presents us with "a theory, not to be esteemed devoutly true, but as, in the present state of knowledge, the most perfect explanation of the known phenomena of the case; and as the least exposed to the many objections easily brought against any other hypothesis."

This passage conveys the drift of the writer's argument, and the 